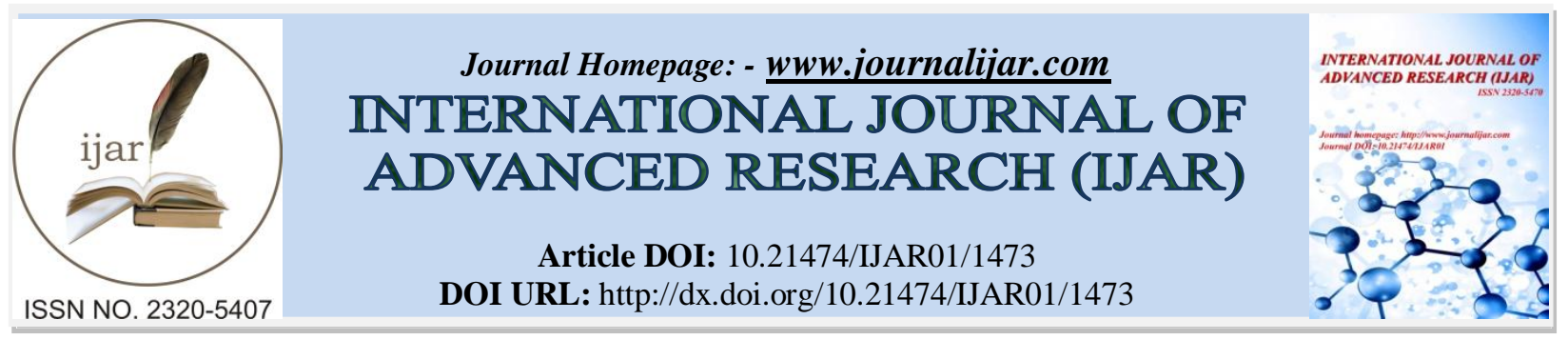

RESEARCH ARTICLE

\title{
DEVELOPMENT AND VALIDATION OF STABILITY INDICATING RP-HPLC METHOD FOR ESTIMATION OF RIFAXIMIN IN BULK AND FORMULATION.
}

\section{S. Sumakala*, S. Vijayaraj and N.R. Dharani.}

Department of Pharmaceutical Analysis, Sree Vidyanikethan College of Pharmacy, Sree Sainath nagar, A. Rangampet, Tirupati; 517102, Chittoor, Andhra Pradesh.

\section{Manuscript Info}

Manuscript History

Received: 12 July 2016

Final Accepted: 13 August 2016

Published: September 2016

Key words:-

Rifaximin, RP-HPLC, Validation, Forced Degradation studies and ICH guidelines.

\section{Abstract}

A reverse-phase high-performance liquid chromatographic method was developed and validated as per ICH guidelines for the determination of Rifaximin in bulk and formulation. The samples were analyzed by high-performance liquid chromatography (HPLC). Chromatographic separation was achieved on an inertsil $\mathrm{C}_{18}(250 \times 4.6$ $\mathrm{mm}$, packed with $5 \mu$ ) column using an aqueous sodium acetate buffer:Acetonitrile (60:40 v/v pH adjusted to 5.0 by using $\mathrm{NaOH}$ ) with flow rate $1.0 \mathrm{ml} / \mathrm{min}$ at ambient temperature and the retention time was about 3.489 minutes. UV detection was found at $293 \mathrm{~nm}$. Linearity was observed over the concentration range of $20-80 \mu \mathrm{g} / \mathrm{ml}$ $\left(R^{2}=0.9997\right)$. The LOD and LOQ were found to be $0.7129 \mu \mathrm{g} / \mathrm{ml}$ and $2.160 \mu \mathrm{g} / \mathrm{ml}$ respectively. Rifaximin was subjected to stress conditions of degradation in aqueous solutions including acidic, alkaline, oxidation and thermal degradation. The forced degradation studies were performed by using $0.1 \mathrm{M} \mathrm{HCl}, 0.1 \mathrm{M} \mathrm{NaOH}, 30 \% \mathrm{H}_{2} \mathrm{O}_{2}$ and thermal at $100^{\circ} \mathrm{C}$. Rifaximin is more sensitive towards acidic conditions in comparison to oxidation and alkaline degradation. The method was validated as per ICH guidelines. The proposed method is simple, specific, selective, precise, linear, cost effective and rapid and is applicable to routine analysis of Rifaximin in bulk and pharmaceutical dosage forms.

Copy Right, IJAR, 2016,. All rights reserved.

\section{Introduction:-}

Rifaximin is a product of synthesis of Rifamycin, an antibiotic with low gastrointestinal absorption and good antibacterial activity. Rifaximin is a semi synthetic non-systemic antibiotic works differently from other antibiotics because it passes through stomach and into intestines without being absorbed into blood stream (Sudha $\mathrm{T}$ and Saminathan J, 2013). Rifaximin is used to treat travellers' diarrhea caused by non-invasive strains of E. coli in adults and children (Sudha T et al., 2009). Rifaximin is also used to treat irritable bowel syndrome and to lower the risk of worsened brain function in adults with liver failure (Hepatic Encephalopathy) (Sandhya B et al., 2011). Rifaximin binds to the beta-subunit of bacterial DNA-dependent RNA polymerase and prevents catalysis of polymerization of deoxyribonucleotides into a DNA strand, thereby inhibiting bacterial RNA synthesis (Kalpana GP et al., 2013). Rifaximin is benzimdazole derivative and chemically it is $2 \mathrm{~S}, 16 \mathrm{Z}, 18 \mathrm{E}, 20 \mathrm{~S}, 21 \mathrm{~S}, 22 \mathrm{R}, 23 \mathrm{R}, 24 \mathrm{R}, 25 \mathrm{~S}$, 26S, 27S, 28E)-5, 6, 21, 23, 25-pentahydroxy-27-methoxy,-2, 4, 11, 16, 20, 22, 24, 26-octamethyl-2, 7(epoxypentadeca-[1, 11 13]trienimino)benzofuro[4, 5-e]pyrido[1,2-a]-benzimida-zole-1, 15(2H)-dione, 25-acetate. 


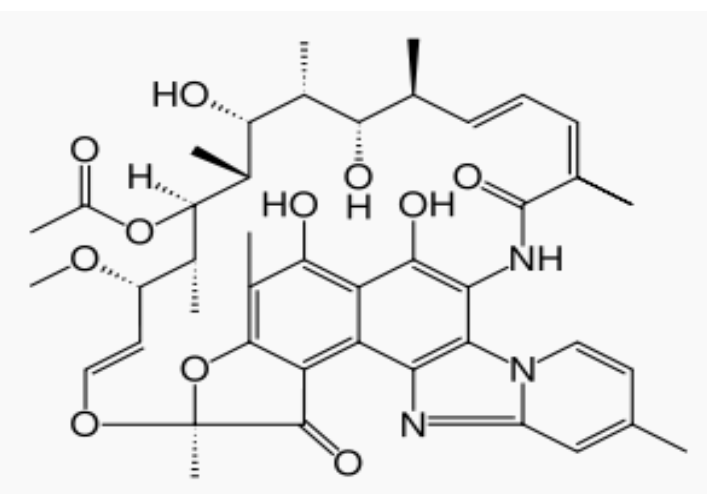

Fig 1:- Chemical Structure of Rifaximin.

Literature survey reveals few analytical methods were reported for the determination of Rifaximin in bulk and pharmaceutical preparations by RP-HPLC (Narendra A et al., 2013, Mathrusri Annapurna M et al., 2014 and Sunitha $\mathrm{P}$ et al., 2015). However the available methods have limitations such as a long runtimes, low sensitivity, uneconomical and have poor symmetry and poor resolution. Keeping in view of these, an attempt has been made to develop a simple, accurate, precise, linear, cost effective and reliable RP-HPLC method for the estimation of Rifaximin in bulk and pharmaceutical dosage forms. The established method was validated with respect to specificity, linearity, precision, accuracy, robustness, LOD and LOQ according to ICH guidelines.

\section{Materials and methods:- Chemicals and solutions:-}

Rifaximin standard (purity $\geq 99.0 \%$ ) and RCIFAX (Label claim: $200 \mathrm{mg}$ ), commercially available tablet dosage form was obtained as free sample from Lupin Pharmaceuticals Limited, Mumbai, India. Sodium acetate, Glacial acetic acid, HPLC grade water, Acetonitrile (HPLC grade), Sodium hydroxide $(\mathrm{NaOH})$, Hydrochloric acid $(\mathrm{HCl})$ and Hydrogen peroxide $\left(\mathrm{H}_{2} \mathrm{O}_{2}\right)$ were obtained from Merck (India). All chemicals were of analytical grade and used as received.

\section{HPLC instrumentation and conditions:-}

Chromatographic separation was achieved by using Inertsil $\mathrm{C}_{18}(250 \mathrm{~mm} \times 4.6 \mathrm{~mm}, 5 \mu)$ column of Waters Model2690 with PDA detector. An automatic injector with $20 \mu \mathrm{l}$ of sample loop was equipped with the HPLC system. The HPLC system was equipped with "Empower 2" data acquisition software. The method was performed using Sodium acetate buffer and Acetonitrile (60:40 v/v) as a mobile phase. The overall run time was $7 \mathrm{~min}$, temperature was ambient and the flow rate was $1.0 \mathrm{ml} / \mathrm{min}$ was injected into the HPLC system.

\section{Preparation of mobile phase:-}

Accurately weighed 32.812 grams of Sodium acetate was taken in 2 liters volumetric flask then $12 \mathrm{ml}$ of Glacial acetic acid was added to dissolve the substance. The volume was made up to mark with HPLC grade water. The pH of resulting solution was adjusted to 5.0 with $\mathrm{NaOH}$. Then filtered through $0.45 \mu$ membrane filter and then sonicated for degassed for $20 \mathrm{~min}$. Acetonitrile was filtered through $0.45 \mu$ membrane filter and then sonicated for degassed for $20 \mathrm{~min}$. Finally, Sodium acetate buffer: Acetonitrile in the ratio of 60:40 v/v (pH 5.0, adjusted with $\mathrm{NaOH}$ ) was used as mobile phase.

\section{Preparation of stock and working standard solutions}

Rifaximin stock solution $(1000 \mu \mathrm{g} / \mathrm{ml})$ was prepared by accurately weighed quantity of $10 \mathrm{mg}$ of Rifaximin in 10 $\mathrm{ml}$ volumetric flask and dissolved in DMSO and the solution made up to volume with mobile phase. Working solutions for HPLC injections were prepared from the stock solution. Solutions were filtered through a $0.45 \mu$ membrane filter prior to injection.

\section{Analysis of marketed formulation (Tablets):-}

Twenty tablets from brand of RCIFAX marketed formulation were weighed individually and powdered to get a fine powder. Powder equivalent to $10 \mathrm{mg}$ Rifaximin was accurately weighed and transferred in to a $10 \mathrm{ml}$ volumetric flask and dissolved in small quantity of DMSO and then the solution is made up the volume with mobile phase. 
Then the solution was sonicated for 20 mins and filtered through $0.45 \mu$ membrane filter before injection. The filtrate obtained from the extracted marketed formulation was diluted as per the requirement and $20 \mu \mathrm{l}$ was injected in to the HPLC system for conducting the assay. Standard and sample solutions were injected into the chromatographic system and recorded the chromatograms, peak areas for the Rifaximin and the peak areas were used for calculating the \% assay of Rifaximin.

\section{Selection of detection wavelength:-}

Weighed quantity of Rifaximin was dissolved in DMSO and the resulting solution was scanned in UV spectroscopy in the range of 200-400 nm. The absorption maximum of Rifaximin was found to be $293 \mathrm{~nm}$.

\section{Method validation (ICH guidelines, 2005):-}

The method was validated according to ICH guidelines for the following parameters:

\section{Precision:-}

Repeatability:-

Method precision: Six sample preparations were prepared individually as per test method and injected in to HPLC.

\section{Intermediate precision (analyst to analyst variability):-}

This study was conducted by two analysts as per test method. The test solution was prepared and injected into the HPLC by two different analysts and the precision study was performed. Results are tabulated in Table 2.

\section{Accuracy (Recovery):-}

A study of Accuracy was performed in triplicate as per test method with equivalent amount of Rifaximin into each volumetric flask for each spike level to get the concentration of Rifaximin equivalent to $50 \%, 100 \%$, and $150 \%$ of the labeled amount as per the test method. The average \% recovery of Rifaximin was calculated. Results are tabulated in table 2 .

\section{Specificity:-}

Solutions of standard and sample were prepared as per the test method and are injected into the chromatographic system. Then the retention times of two chromatograms were compared with each other.

\section{Linearity of test Method:-}

A Series of solutions were prepared using Rifaximin working standard at concentration range from $20 \mu \mathrm{g} / \mathrm{ml}$ to $80 \mu \mathrm{g} / \mathrm{ml}$ of target concentration. The prepared concentrations were injected into the HPLC and peak areas were measured. Then the calibration curve was plotted by taking concentration on $\mathrm{X}$-axis and peak area on $\mathrm{Y}$-axis shown in Fig 3. From the linearity data the limit of detection (LOD) and limit of quantitation (LOQ) was calculated.

\section{Robustness:-}

A study was conducted to determine the effect of variation in flow rate. Standard solution prepared as per the test method and was injected into the HPLC system. Results are tabulated in table 4.

\section{Ruggedness of Test Method:-}

System to system variability study was conducted on different HPLC systems, under similar conditions at different times. Six samples were prepared and injected into the HPLC and each was analyzed as per test method.

\section{System Suitability:-}

A Standard solution was prepared by using Rifaximin working standard as per test method and was injected five times into the HPLC system.

\section{Forced degradation studies (ICH guidelines, 2003):-}

Forced degradation studies were performed to evaluate the stability indicating properties and specificity of the developed method. All solutions used in stress conditions were prepared at an initial concentration of $1 \mathrm{mg} / \mathrm{ml}$ of Rifaximin and refluxed at $60^{\circ} \mathrm{C}$ for $4 \mathrm{hrs}$. Then all sample solutions were diluted with mobile phase to get a final concentration of $10 \mu \mathrm{g} / \mathrm{ml}$ and filtered before injection (Shete $\mathrm{S}$ et al., 2014). 


\section{Acid and alkali degradation studies:-}

Acid decomposition was carried out in $0.1 \mathrm{M} \mathrm{HCl}$ at a concentration of $10 \mu \mathrm{g} / \mathrm{ml}$ of Rifaximin and after refluxation at $60{ }^{\circ} \mathrm{C}$ for $4 \mathrm{hrs}$ in thermostat the stressed sample was cooled at room temperature, neutralized and diluted with mobile phase. Similarly stress studies in alkaline conditions were conducted using a concentration of $10 \mu \mathrm{g} / \mathrm{ml}$ in 0.1 $\mathrm{M} \mathrm{NaOH}$ and refluxed at $60^{\circ} \mathrm{C}$ for $4 \mathrm{hrs}$ in thermostat and cooled at room temperature. After cooling the solution was neutralized and diluted with mobile phase.

\section{Oxidative degradation studies:-}

Forced degradation studies in oxidative conditions was performed by the addition of an aliquot of stock solution (1 $\mathrm{mg} / \mathrm{ml}$ ) of Rifaximin was added to $10 \mathrm{ml}$ of $30 \% \mathrm{H}_{2} \mathrm{O}_{2}$ solution and the mixture was refluxed at $60^{\circ} \mathrm{C}$ for approximately 4 hours. The solution was kept aside for few min to reach the room temperature and diluted to $100 \mathrm{ml}$ with the mobile phase, so as to get a final concentration of $10 \mu \mathrm{g} / \mathrm{ml}$.

\section{Thermal degradation:-}

Accurately weighed $50 \mathrm{mg}$ of Rifaximin drug and was stored at $100^{\circ} \mathrm{C}$ in a hot air oven for 24 hours. Then it was dissolved in small quantity of DMSO and transferred into a $50 \mathrm{ml}$ volumetric flask and the volume was adjusted to $50 \mathrm{ml}$ with the mobile phase. The above solution was further diluted with the mobile phase, to get a solution of final concentration equivalent to $10 \mu \mathrm{g} / \mathrm{ml}$ of Rifaximin. Results are tabulated in Table 4.

\section{Results and Discussion:-}

Table 1:- The optimised chromatographic conditions.

\begin{tabular}{|l|l|}
\hline \multicolumn{1}{|c|}{ Parameters } & \multicolumn{1}{c|}{ Method } \\
\hline Stationary phase (column) & $\begin{array}{l}\text { Inertsil }- \text { ODS C } 18 \\
(250 \times 4.6 \mathrm{~mm}, \text { packed with 5 micron) }\end{array}$ \\
\hline Mobile Phase & Sodium Acetate Buffer : Acetonitrile $(60: 40 \mathrm{v} / \mathrm{v})$ \\
\hline Ionic strength of buffer & $0.2 \mathrm{M}$ \\
\hline $\mathrm{pH}$ & 5 \\
\hline Flow rate $(\mathrm{ml} / \mathrm{min})$ & $1.0 \mathrm{ml} / \mathrm{min}$ \\
\hline Run time $($ minutes) & 7 \\
\hline Column temperature $\left({ }^{\circ} \mathrm{C}\right)$ & Ambient \\
\hline Volume of injection loop $(\mu \mathrm{l})$ & 20 \\
\hline Detection wavelength $(\mathrm{nm})$ & $293 \mathrm{~nm}$ \\
\hline Drug RT $(\mathrm{min})$ & 3.469 \\
\hline
\end{tabular}

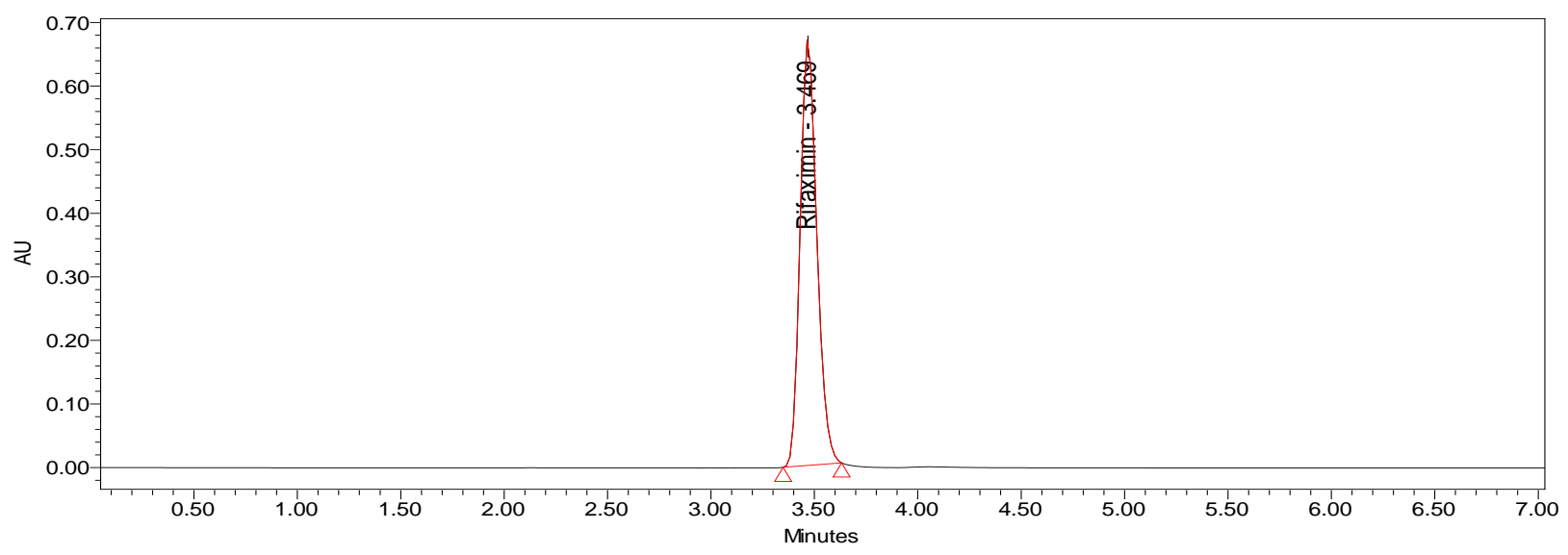

Fig 2:- Representative chromatogram of Rifaximin peak in optimized mobile phase 
Intermediate Precision:-

Table 2:- Data of Intermediate precision (b/w Analyst-1 and Analyst-2) for Rifaximin.

\begin{tabular}{|c|c|c|c|}
\hline \multirow[t]{2}{*}{ No. of Injections } & \multirow[t]{2}{*}{ Concentration $(\mu \mathrm{g} / \mathrm{ml})$} & \multicolumn{2}{|c|}{ Peak area of Rifaximin } \\
\hline & & Analyst-1 & Analyst-2 \\
\hline 1 & \multirow{6}{*}{40} & 1257189 & 1236712 \\
\hline 2 & & 1241965 & 1265245 \\
\hline 3 & & 1253298 & 1259876 \\
\hline 4 & & 1266242 & 1258124 \\
\hline 5 & & 1249726 & 1241638 \\
\hline 6 & & 1251933 & 1244419 \\
\hline Mean peak area & & 1253392 & 1251002 \\
\hline Mean & \multicolumn{3}{|c|}{1252197} \\
\hline S.D & \multicolumn{3}{|c|}{1689.985} \\
\hline$\%$ RSD & \multicolumn{3}{|c|}{0.1349616} \\
\hline
\end{tabular}

Intermediate precision was performed by two analysts. Mean, SD and \% RSD values were calculated. The \% RSD was found to be within the limits and the developed method was found to be precise Table 2 .

\section{Accuracy (Recovery)}

Table 3:- Data of Accuracy studies for Rifaximin.

\begin{tabular}{|c|c|c|c|c|c|c|c|}
\hline \multirow[t]{2}{*}{$\begin{array}{l}\text { Concentration } \\
\% \text { of spiked level }\end{array}$} & \multirow[t]{2}{*}{$\begin{array}{c}\text { Amount added } \\
(\mu \mathrm{g} / \mathrm{ml})\end{array}$} & \multicolumn{3}{|c|}{$\begin{array}{l}\text { Amount found } \\
(\mu \mathrm{g} / \mathrm{ml}) \mathrm{n}=3\end{array}$} & \multicolumn{3}{|c|}{ Statistical Analysis of \% Recovery } \\
\hline & & 1 & 2 & 3 & $\begin{array}{c}\text { Mean of \% } \\
\text { Recovery }\end{array}$ & $\begin{array}{l}\text { SD of \% } \\
\text { recovery }\end{array}$ & $\%$ RSD \\
\hline $50 \%$ & 20 & 19.95 & 19.86 & 20.08 & 99.81 & 0.5530 & 0.5540 \\
\hline $100 \%$ & 40 & 40.14 & 39.96 & 39.80 & 99.91 & 0.4252 & 0.4255 \\
\hline $150 \%$ & 60 & 59.89 & 60.04 & 60.09 & 100.007 & 0.1761 & 0.1760 \\
\hline
\end{tabular}

The mean \% recovery of the Rifaximin at each spike level should be not less than $98.0 \%$ and not more than $102.0 \%$ as per the acceptable limit, hence the obtained datas at 50\%, 100\% and 150\% levels were within the acceptable limit.

\section{Specificity:-}

The specificity study for Rifaximin was performed. The chromatograms of Standard and Sample were found to be identical with near retention time and the developed method was found to be specific.

\section{Linearity:-}

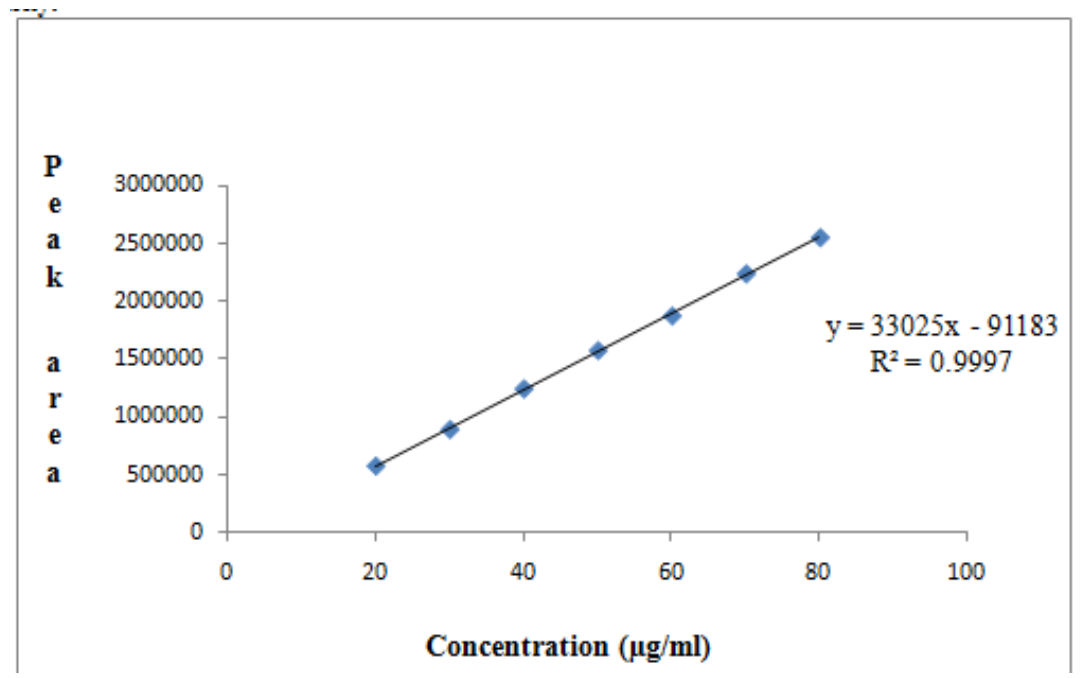

Fig 3:- Linearity curve of Rifaximin (Concentration Vs Peak area). 
Linearity studies were performed. A calibration curve was plotted. The calibration curve was linear with slope, yintercept and correlation coefficient were found to be 33025, 91183 and 0.999 respectively. From the linearity curve the LOD and LOQ are calculated as $0.7129 \mu \mathrm{g} / \mathrm{ml}$ and $2.160 \mu \mathrm{g} / \mathrm{ml}$ respectively.

Robustness:-

Table 4:- Data for Effect of variation in flow rate for Rifaximin.

\begin{tabular}{|c|c|c|c|c|c|c|}
\hline \multirow{2}{*}{$\begin{array}{c}\text { No. of } \\
\text { Injections }\end{array}$} & \multicolumn{2}{|c|}{ Flow rate $0.8 \mathrm{ml} / \mathrm{min}$} & \multicolumn{2}{|c|}{ Flow rate $1.0 \mathrm{ml} / \mathrm{min}$} & \multicolumn{2}{|c|}{ Flow rate $1.2 \mathrm{ml} / \mathrm{min}$} \\
\hline & Std area & Tailing Factor & Std area & Tailing Factor & Std area & Tailing Factor \\
\hline 1 & 1239361 & 1.133372 & 1239678 & 1.146235 & 1249381 & 1.129133 \\
\hline 2 & 1243411 & 1.164125 & 1243389 & 1.129133 & 1254986 & 1.159150 \\
\hline 3 & 1237979 & 1.123397 & 1264984 & 1.159150 & 1247372 & 1.141469 \\
\hline 4 & 1246482 & 1.125612 & 1248352 & 1.141469 & 1256493 & 1.130372 \\
\hline 5 & 1241537 & 1.123857 & 1248352 & 1.130372 & 1239664 & 1.133372 \\
\hline $\begin{array}{l}\text { Mean peak } \\
\text { area }\end{array}$ & 1241754 & 1.134073 & 1248951 & 1.141272 & 1249579 & 1.138699 \\
\hline \multicolumn{7}{|c|}{$\frac{\text { ate of } 0.8 \mathrm{ml} / \mathrm{min} \mathrm{a}}{1245353}$} \\
\hline$\frac{\text { SD }}{\% \text { RSD }}$ & \multicolumn{3}{|c|}{5089.048} & \multicolumn{3}{|c|}{444.2045} \\
\hline
\end{tabular}

The Tailing Factor and \% RSD of Rifaximin standards should be NMT 2.0 for Variation in Flow rate. Robustness studies were performed for effect of variation in flow rate for Rifaximin drug at different flow rates like $0.8 \mathrm{ml} / \mathrm{min}$, $1 \mathrm{ml} / \mathrm{min}$ and $1.2 \mathrm{ml} / \mathrm{min}$. The tailing factor for Rifaximin and \% RSD were found to be within the limits.

\section{Ruggedness:-}

The ruggedness (system to system variability) studies were performed for Rifaximin drug by two systems. Six replicates were prepared as per test method and measured in HPLC. Then the mean, SD and \% RSD were calculated. The \% RSD value of Rifaximin was found to be 0.2461 which is within the limits.

\section{System Suitability Studies:-}

The system suitability parameters were evaluated from standard chromatograms. The number of theoretical plates (NTM 3000), tailing factor (NMT 2) and \% RSD of retention times, peak areas, theoretical plate count and tailing factor were found to be $0.0632,0.5251,1.6275$ and 1.5231 respectively which are within the limits.

\section{Assay:-}

The \% assay of the Rifaximin drug was found to be $100.72 \%$ which was found to be within the acceptable limits $(98-102 \%)$.

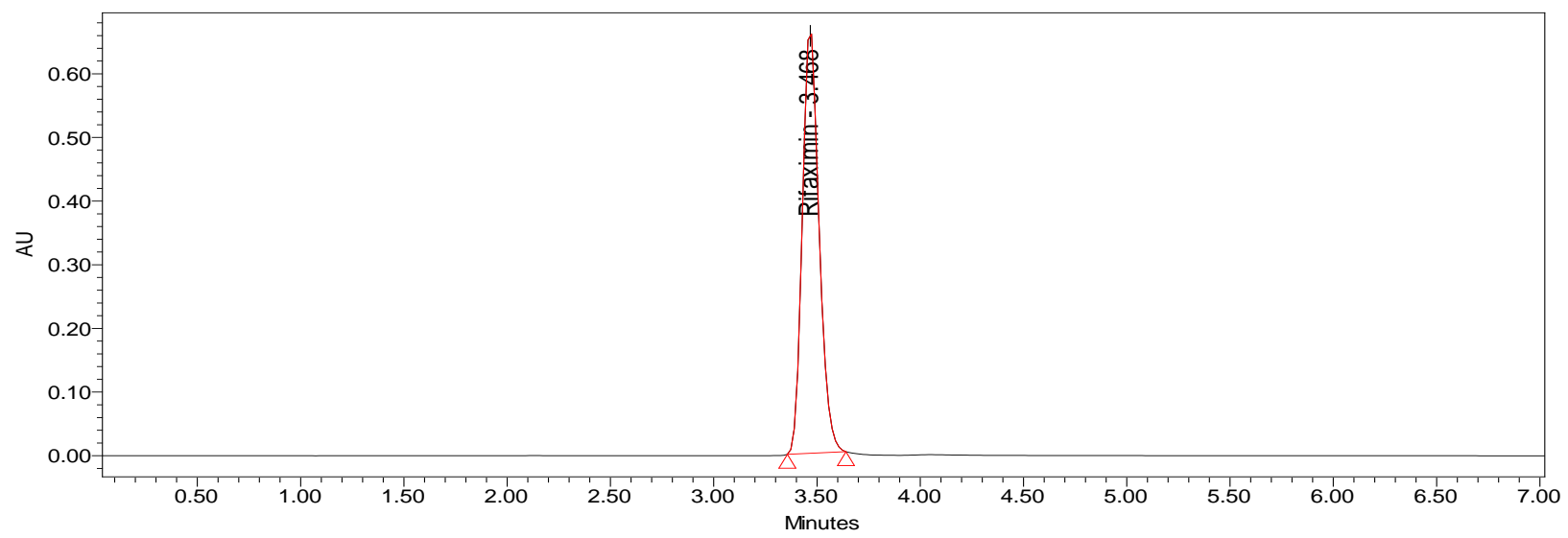

Fig 4:- Representative chromatogram of Rifaximin for assay. 
Forced Degradation Studies:-

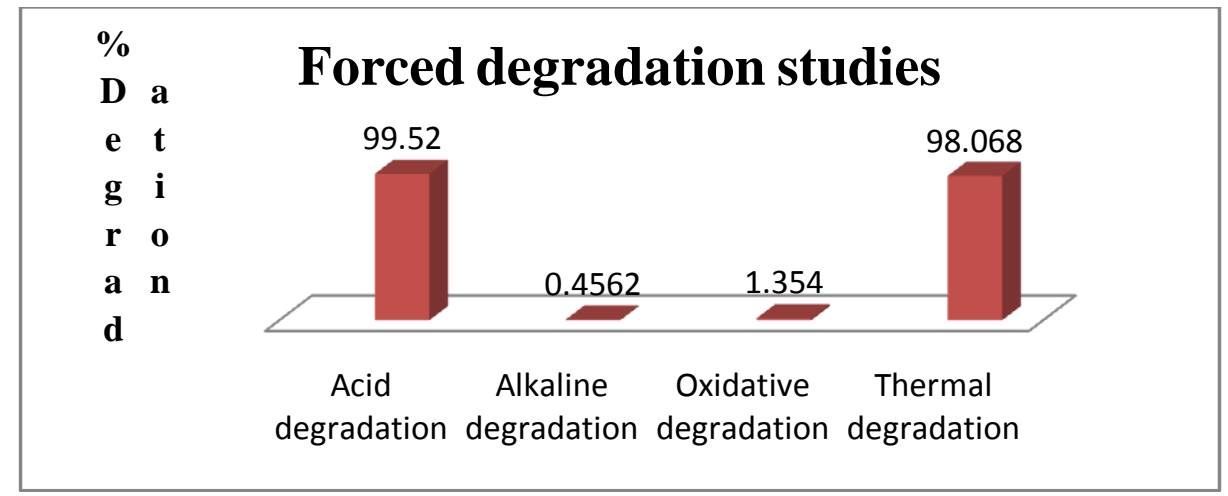

Fig 5:- Forced Degradation studies for Rifaximin.

Forced degradation studies were performed for the Rifaximin drug under various stress conditions. Degradation of Rifaximin drug in acidic condition is $99.52 \%$. Degradation of Rifaximin drug in alkaline condition is $0.4562 \%$. Degradation of Rifaximin drug in oxidative condition is $1.3540 \%$. Degradation of Rifaximin drug in thermal condition is $98.068 \%$. The amount of drug degradation was found to be more in acidic condition. The drug was stable in alkaline condition.

\section{Conclusion:-}

A new stability indicating method was established for the estimation of Rifaximin by RP-HPLC method. The developed and validated RP-HPLC method was found to be simple, specific, precise, accurate, linear and cost effective for estimation of Rifaximin in bulk and formulations. The developed method was validated as per the ICH guidelines and the results obtained were well within the limits. Forced degradation study of Rifaximin shown that the amount of drug degradation was found to be more in acidic medium (99.52\%) and the drug was found to be more stable in alkaline medium $(0.4562 \%)$. The statistical analysis of the developed method confirms minimal deviation and all the validation parameter was well within the specified range. Hence the developed method can be successfully applied for analysis of Rifaximin in bulk and formulation.

\section{Acknowledgements:-}

The authors would like to thank Lupin Pharmaceuticals Ltd., Mumbai, India for providing the samples of Rifaximin. We are highly grateful to Dr. M. Mohan babu, Chairman, Sree Vidyanikethan College of Pharmacy, Sree Sainath nagar, A. Rangampet, Tirupati for providing the necessary facilities to carry out this research work.

\section{Conflict of interest statement:-}

The authors hereby declare that there are no conflicts of interest in the proposed article.

\section{References:-}

1. ICH Stability Testing of New Drug Substances and Products (2 ${ }^{\text {nd }}$ Revision) Q1A (R2), (2003): International Conference on Harmonization.

2. ICH Validation of analytical procedures: Text and methodology Q2 (R1), (2005): International Conference on Harmonization.

3. Kalpana GP, Nitesh RJ, and Purvi AS. (2013): Stability Indicating HPTLC Method for Analysis of Rifaximin in Pharmaceutical Formulations and an Application to Acidic Degradation Kinetic Study, ISRN Analytical Chemistry. 1-9.

4. Mathrusri Annapurna M, Sai Pavan Kumar B, Venkatesh B and Raj Prakash J. (2014): Development and Validation of Stability-Indicating Liquid Chromatographic Assay for Rifaximin (An Antibiotic) in Bulk and Pharmaceutical Dosage Forms, Chemical Science Transactions. 3(2): 566-575.

5. Narendra A, Mathrusri Annapurna M, Ravi Kumar K. (2013): Development and validation of the stability indicating liquid chromatographic method for Rifaximin -an antibiotic, Journal of Drug Delivery \& Therapeutics, 3(2): 18-25. 
6. Sandhya B. et al., (2011): RP-HPLC Method Development And Validation For The Analysis of Rifaximin in Pharmaceutical Dosage Forms, IJRRPAS, 1(4): 323-333.

7. Shete S, Dhale C, Joshi S, Hole R. (2014): Force Degradation Study To Stability Indicating Method, World Journal of Pharmacy and Pharmaceutical Sciences, 3(8): 863-873.

8. Sudha T, Hemalatha P V, Ravikumar V R, Jothi R, and Radhakrishnan M. (2009): Development and validation of RP-HPLC method for the estimation of Rifaximin in bulk and in tablet dosage form, Asian Journal of Pharmaceutical and Clinical Research, 2(4): 112-116.

9. Sudha T, Saminathan J. (2013): Development and Validation of HPTLC Method for the Estimation of Rifaximin Bulk and in Tablet Dosage Forms, PhTechMed. 2(3): 300-302.

10. Sunitha P, Avanti M, Vijaya K. (2015): A Stability Indicating Method for the Estimation of Rifaximin in its Bulk and Pharmaceutical Dosage Form by RP-HPLC Method, International Journal of Chemical and Pharmaceutical Analysis, 2(2): 111-116. 